\title{
Pelatihan Digital Marketing Memanfaatkan Sosial Media dan Marketplace pada Usaha Dekorasi dan Catering Pernikahan
}

\author{
${ }^{1 *}$ Shofwan Hanief, ${ }^{2}$ Ni Nyoman Utami Januhari, ${ }^{3}$ A.A Ratu Asmara \\ Program Studi Sistem Informasi ITB STIKOM Bali ${ }^{1,2,3}$ \\ Email: hanief@stikom-bali.ac.id ${ }^{1}$,amik@stikom-bali.ac.id², asmara@stikom-bali.ac.id ${ }^{3}$
}

\begin{abstract}
ABSTRAK
Resepsi pernikahan yang merupakan salah satu rangkaian kegiatan dari sebuah pernikahan yang tujuan utamanya adalah memberikan informasi kepada orang terdekat bahwa telah terjalin ikatan sah antara seorang lelaki dan perempuan. Terkait hal tersebut perlu dilakukan persiapan seperti dekorasi, jamuan makan minum, sampai ke tata rias pengantin dalam pelaksanaannya. UKM Okky Dhelima Decoration adalah salah satu dari banyaknya usaha jasa di bidang dekorasi, catering dan rias pengantin di kabupaten Karangasem yang telah berjalan selama 7 tahun dan beralamat di Jl. Diponegoro no. 14 kota Amlapura kabupaten Karangasem. Saat ini pemasaran yang dilakukan secara tradisional dari mulut ke mulut atau membuat brosur untuk dibagikan atau ditempel di tempat-tempat yang strategis yang dapat diakses, hasilnya yang didapat oleh UKM Okky Dhelima Decoration masih sangat minim, dengan pencapaian pemesanan baik paket (all in one) ataupun jasa tunggalnya sebanyak 1 hingga 4 pesanan per bulan, dan hal ini yang menjadi masalah pada mitra saat ini. Kegiatan pengabdian kali ini difokuskan bagaimana melakukan pemasaran pada mitra dengan memanfaatkan sosial media khususnya facebook, dan marketplace shopee, sehingga penyebaran untuk memasarkan usaha ini menjadi lebih luas. Metode pelaksanaan yang dilakukan dengan cara, seminar, workshop, pelatihan, dan evaluasi kegiatan. Hasil dari kegiatan pengabdian masyarakat ini adalah peningkatan wawasan dan keterampilan karyawan di UKM Okky Dhelima Decoration Meningkat $100 \%$ dan peningkatan pemesanan jasa Okky Dhelima Decoration yang sebelumnya maksimal 4 pesanan menjadi 6 pesanan.
\end{abstract}

Kata kunci : Pemasaran, Media Sosial, Marketplace

\section{ABSTRACT}

Wedding ceremony is one of a series of activities in a marriage whose main purpose is to provide information to the closest people that there has been a legal bond between a man and a woman. With that it is necessary to make preparations such as decorations, banquets, to bridal make-up in its implementation. UKM Okky Dhelima Decoration is one of the many service businesses in the field of decoration, catering and bridal make-up in Karangasem district which has been running for 7 years and is located at Jl. Diponegoro no. 14 cities of Amlapura, Karangasem regency. Currently, marketing is done traditionally by word of mouth or making brochures to be distributed or posted in strategic places that can be accessed, the results obtained by UKM Okky Dhelima Decoration are still very minimal, with the achievement of good package orders (all in one) or a single service of 1 to 4 orders per month, and this is a problem with current partners. This service will focus on how to do marketing to partners by utilizing social media, especially Facebook, and the shopee marketplace, so that the distribution to market this business becomes wider. The method of implementation is carried 
out by means of seminars, workshops, training, and evaluation of activities. The results of this community service activity are an increase in the insight and skills of employees at UKM Okky Dhelima Decoration into 6 orders.

Keywords: Marketing, Social Media, Marketplace

\section{PENDAHULUAN}

Resepsi pernikahan yang merupakan salah satu rentetan kegatan dari sebuah pernikahan adalah sebuah cara yang tujuan utamanya adalah memberikan informasi kepada saudara, tetangga, handai taulan dan kerabat bahwa sepasang lelaki dan perempuan yang sudah sah menjadi suamiistri. Dengan adanya acara resepsi maka perlu dilakukan persiapan seperti dekorasi, jamuan makan minum (Marahimin, Hiang. 2008), sampai tata rias pengantin yang tujuannya memberikan kebahagiaan kepada saudara, tetangga, dan kerabat terdekat.

Berdasarkan data yang diambil dari websiter resmi Pemerintah provinsi kabupaten Karangasem http://v2.karanga semkab.go.id/index.php/profil, kabupaten Karangasem terdiri dari 8 kecamatan, 3 kelurahan, dan 75 desa. Pada tahun 2017, jumlah penduduknya mencapai 545.389 jiwa dengan luas wilayah $839,54 \mathrm{~km}^{2}$ dan sebaran penduduk 650 jiwa $/ \mathrm{km}^{2}$. Dalam kegiatan usahanya UKM Okky Dhelima Decoration adalah salah satu dari banyaknya usaha jasa dibidang dekorasi, catering dan rias pengantin di kabupaten Karangasem. Bisnis ini telah digeluti selama 7 tahun dan beralamat di $\mathrm{Jl}$. Diponegoro no. 14 kota Amlapura kabupaten Karangasem dengan melakukan pemasaran dari mulut ke mulut atau membuat brosur untuk dibagikan atau ditempel di tempat-tempat yang strategis dan dapat diakses oleh masyarakat umum.
Dengan cara pemasaran seperti itu hasil yang didapat oleh UKM Okky Dhelima Decoration masih sangat minim, dengan pencapaian pemesanan baik paket (all in one) ataupun jasa tunggalnya sebanyak 1 hingga 4 pesanan setiap bulan. Berikut adalah salah satu gambar peralatan untuk resepsi yang biasa disewakan oleh Okky Dhelima Decoration.

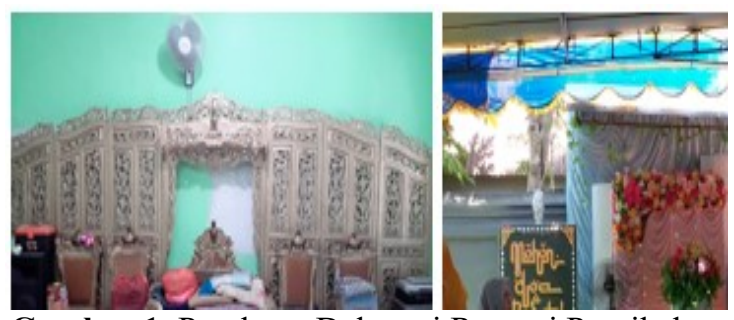

Gambar 1. Peralatan Dekorasi Resepsi Pernikahan

Minimnya informasi yang tersebar mengenai usaha dari UKM Okky Dhelima Decoration ini mengakibatkan tidak seluruh wilayah di kabupaten Karangasem mengetahui keberadaan dari UKM Okky Dhelima Decoration ini. Selain itu, pesatnya media teknologi informasi dan komunikasi yang saat ini sudah menjangkau sampai ke pelosok di wilayah kabupaten Karangasem. Kemajuan ini menjadi peluang dalam memasarkan usaha yang digeluti oleh Okky Dhelima Decoration. Berdasarkan informasi yang pernah dimuat di https://metrobali.com /tinggi-pengguna-internet-di-bali, bahwa ada 7 dari 10 masyarakat di kabupaten Karangasem adalah pengguna gadget, yang di antaranya adalah jenis gadget yang sudah terhubung ke Intenet. 
Kegiatan pengabdian ini terfokus pada bagaimana pengelolaan pemasaran pada UKM Okky Dhelima Decoration ini dengan memanfaatkan media sosial khususnya facebook, dan marketplace shopee, sehingga penyebaran untuk memasarkan usaha ini menjadi lebih luas. Pesatnya media berbasis teknologi dan digital memungkinkan para pelaku usaha melakukan penetrasi secara luas, hal ini disebabkan sudah semakin tergantungnya manusia dengan teknologi dan gadget dalam kehidupan (Yuswohady, F.Fatahillah, B.Tryaditia, A.Rachmaniar. 2019). Dipilihnya dua platform tersebut dalam pengabdian masyarakat karena jumlah anggota pada kedua platform tersebut adalah salah satu yang terbanyak, dan juga kedua platform tersebut paling familiar untuk digunakan (Helianthusonfri, Jefferly. 2017). Target luaran yang ingin dicapai melalui kegiatan pengabdian ini adalah UKM Okky Dhelima Decoration mampu mengelola memasarkan usahanya dengan memanfaatkan teknologi internet khususnya media sosial dan internet, sehingga pengguna dari jasa UKM Okky Dhelima Decoration akan terus meningkat setiap bulannya.

\section{RUMUSAN MASALAH}

Berdasarkan latar belakang yang terdapat pada pendahuluan, maka rumusan masalah dalam kegiatan ini adalah sebagai berikut:

a) Tidak terdapat media pemasaran efektif untuk memperkenalkan usaha UKM Okky Dhelima Decoration.

b) Kesadaran UKM Okky Dhelima Decoration akan manfaat dari media sosial dan marketplace untuk mendukung pemasaran pada usaha jasa dekorasi, catering, dan rias pengantin belum tampak

\section{METODE}

Adapun tahapan kegiatan yang telah dilakukan pada kegiatan pengabdian masyarakat ini diuraikan pada Gambar 2. Bentuk kegiatan utama antara lain sosialisasi kegiatan, workshop tentang digital marketing, pelatihan pembuatan akun email, facebook, dan marketplace, sampai tahap evaluasi.

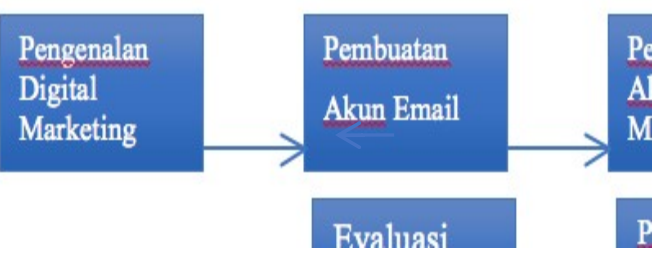

Gambar 2. Tahapan Kegiatan

Prosedur kerja dan rencana kegiatan yang telah dilaksanakan dalam pengabdian ini adalah sebagai berikut:

1. Pengenalan Digital Marketing

2. Pembuatan Akun Email

3. Pembuatan Akun Sosial Media

4. Pelatihan Pemasaran Digital

5. Evaluasi Kegiatan Pelatihan

6. Pendampingan

\section{PEMBAHASAN}

Sebagai salah satu dari pelaksanaan tri dharma perguruan tinggi yaitu kegiatan pengabdian masyarakat, dalam kesempatan ini yang dilakukan pada UKM dimaksud yakni kegiatan pengabdian dalam bentuk workshop dan pelatihan kepada UKM Okky Dhelima Decoration. Kegiatan pengabdian ini adalah kelanjutan dari kegiatan yang sudah dilakukan di sesi pertama yang dilakukan dengan cara pertemuan fisik dan dihadiri oleh peserta dalam hal ini 
para karyawan dari UKM Okky Dhelima Decoration yang menjalankan usaha ini dan tim pengabdian dari ITB STIKOM Bali. Oleh karena kondisi pandemik global saat ini, workshop dan pelatihan dilakukan hanya kepada pemilik UKM saja yaitu ibu Okky Dhelima, dengan alasan keterbatasan kuota atau koneksi internet pada mitra pengabdian. Materimateri workshop disampaikan melalui video conference, sedangkan untuk pelatihan diberikan tutorial dengan pendampingan jarak jauh.

Kegiatan ini dilakukan oleh tim pada tanggal 5 Juni 2020 pada pukul 09:00 s/d 16:00 WITA. Workshop dilakukan tim dari ITB STIKOM Bali dengan memberikan materi workshop kepada pemilik usaha UKM Okky Dhelima Decoration melalui video conference. Pelatihan dilakukan secara jarak jauh dengan cara memberikan tutorial kepada mitra lalu mendemokan melalui video conference. Setelah sesi materi, UKM Okky Dhelima Decoration diberikan kesempatan untuk melakukan pembuatan email, akun facebook, dan akun marketplace secara mandiri dengan pendampingan secara jarak jauh. Di saat terjadi permasalahan atau kesulitan, mitra dapat berkomunikasi melalui kanal-kanal yang tersedia seperti whatsapp, email, ataupun video conference.

Kegiatan ini telah berlangsung secara daring dengan menggunakan teknologi informasi dan komunikasi, aplikasi video conference zoom, email, dan Whatsapp. Kegiatan pengabdian pada UKM Okky Dhelima Decoration yang bergerak di bidang jasa penyewaan alat dan rias pengantin serta catering ini berlangsung dengan tahapan sebagai berikut.

\section{Pembukaan dan ramah tamah}

Pembukaan dilakukan secara daring dengan menggunakan aplikasi video conference zoom. Pada saat pembukaan ini dihadiri oleh tim dari ITB STIKOM Bali dan UKM Okky Dhelima Decoration dengan menggunakan sebuah laptop pada tim pelaksana pengabdian dan 1 laptop pada UKM Okky Dhelima Decoration, karena alasan koneksi yang tidak stabil pada mitra pengabdian. Pada pembukaan dan ramah tamah dilakukan analisis situasi terhadap mitra dan menggali permasalahan yang terjadi pada mitra pengabdian saat ini.

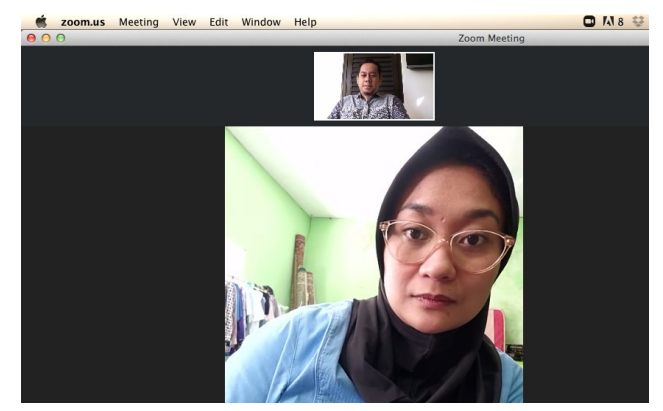

Gambar 3. Pembukaan dan Ramah Tamah Via Daring

\section{Workshop Sesi 1: Digital marketing}

Setelah dilakukan pembukaan dan ramah tamah selama 30 menit didapatkan analisis situasi bahwa kondisi mitra saat ini sangat terbatas pada sisi pemasaran jasa dekorasi, catering, dan rias pengantin di wilayah kabupaten Karangasem pada khususnya. Sehingga dilakukan sebuah workshop mengenai digital marketing dengan materi seperti yang terdapat pada gambar 4 berikut. 


\section{PEMASARAN PRODUK UK INTERNET}

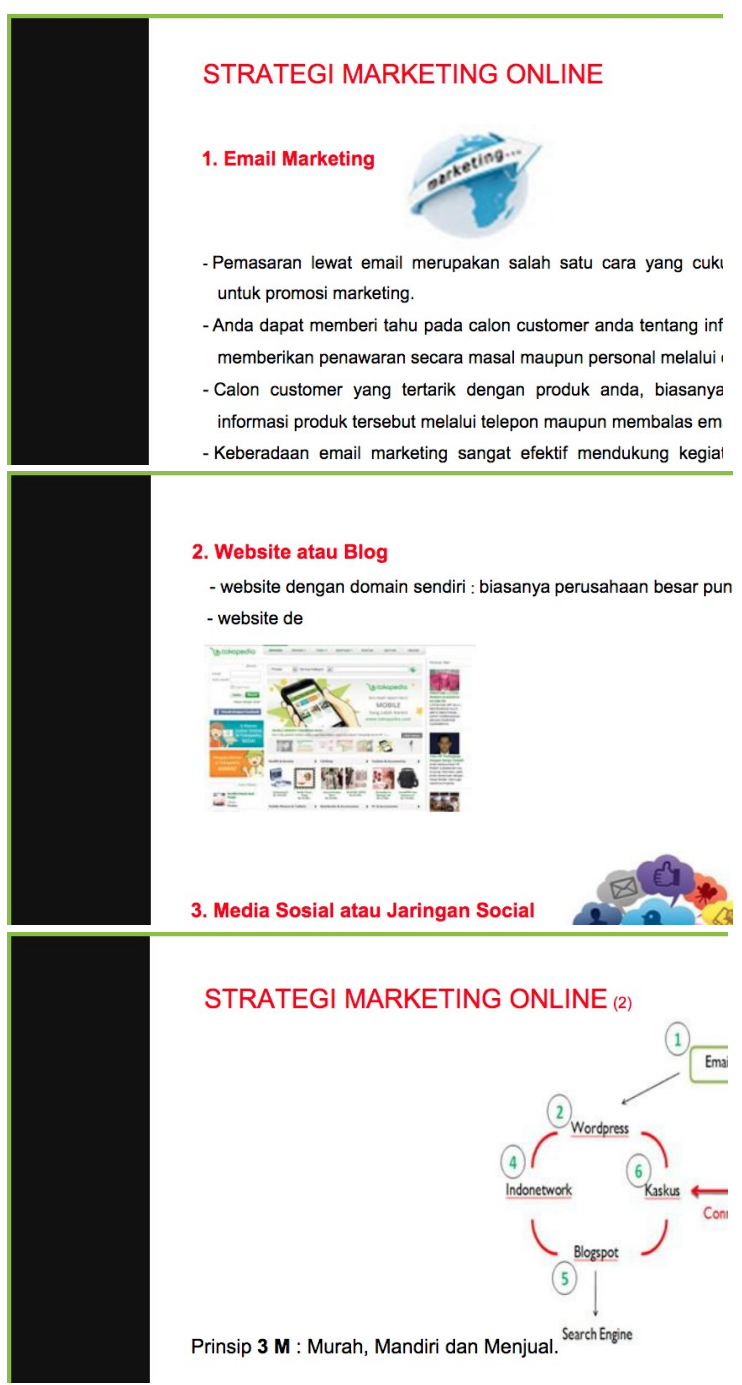

Gambar 4. Workshop Digital Marketing Via Daring
Selanjutnya dilakukan sesi tanya jawab kepada mitra agar mitra lebih memahami materi tentang digital marketing ini lebih memahami mengenai pemaparan digital marketing, keuntungan dari digital marketing, penetrasinya, dan media apa saja yang dapat digunakan untuk melakukan pemasaran dengan media digital seperti yang terdapat pada gambar 5 berikut. Untuk sesi tanya jawab dilakukan dengan menggunakan media video conference seperti pada saat dilakukan workshop.

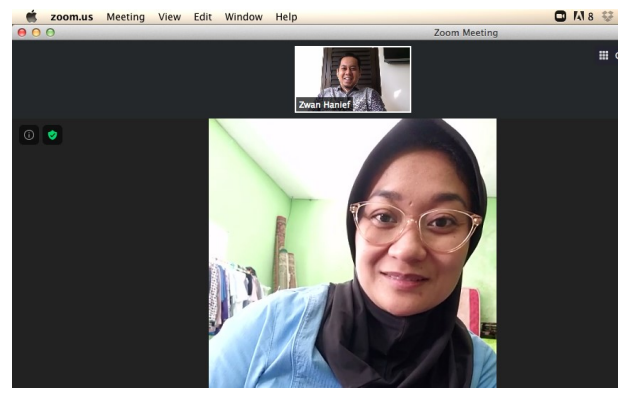

Gambar 5. Tanya Jawab Via Daring

\section{Workshop Sesi 2: Pengenalan Media Pemasaran Digital}

Setelah mitra mendapatkan pengetahuan mengenai Digital Marketing pada saat workshop sesi 1, maka di sesi ini dilakukan workshop dengan mengenalkan mitra pada beberapa marketplace yang gratis untuk pemasaran usaha mitra di kabupaten Karangasm khususnya, dan provinsi Bali umumnya. Pada workshop sesi 2 ini dilakukan pengenalan tentang marketplace seperti shopee, lazada, bukalapak, olx, dan yang lainnya (Wiradarma IGN, Sukarsa I Made, Sutramiani Ni Putu. 2019) yang dapat digunakan untuk pemasaran usaha mitra.

\section{Tanya jawab}




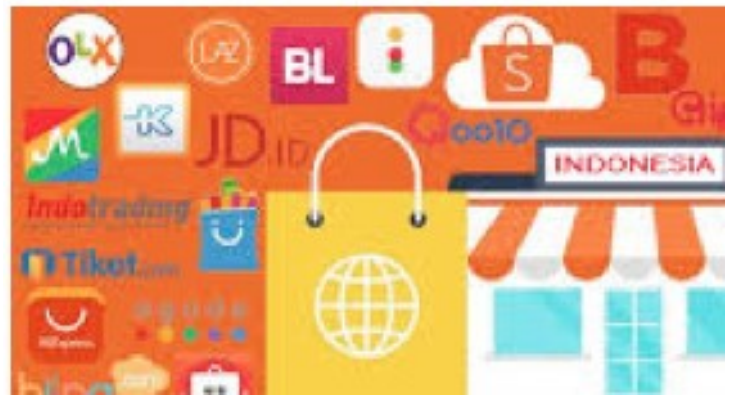

Gambar 6. Workshop Sesi 2

\section{Ishoma}

Setelah dilakukan workshop sesi 2, kegiatan dihentikan sementara waktu untuk ishoma. Kegiatan ini dilakukan pada hari Jum'at sehingga ishoma dilakukan selama 90 menit untuk memberikan kesempatan kepada mitra dan tim pengabdian masyarakat untuk ibadah sholat Jum'at.

\section{Pelatihan Pembuatan Akun email, Facebook, dan Marketplace}

Tahap selanjutnya pada kegiatan pengabdian masyarakat ini adalah memberikan pelatihan mengenai pemasaran secara digital dengan menggunakan media sosial. Pelatihan ini bersifat jarak jauh dengan cara memberikan tutorial kepada mitra untuk melakukan pembuatan akun email, facebook, dan marketplace. Adapun pelatihan kegiatan ini adalah sebagai berikut :

a. Pembuatan akun gmail

Pada sesi ini, mitra diberikan tutorial untuk membuat akun gmail sendiri, namun sebelumnya dilakukan demo bagaimana membuat akun gmail, sehingga mitra mendapatkan gambaran langkah-langkah membuat akun gmail dengan melihat pada tutorial yang sudah diberikan. Berikut adalah langkah-langkah pembuatan akun email pada saat pelatihan dilakukan.

I. Langkah paling awal, siapkan koneksi internet, 2. Masukan alamatnya urulnya http://mail.google.con Sehingga tampil gambar seperti di bawah ini. Kemuc an account] atau Buat Akun yang berada di pojo

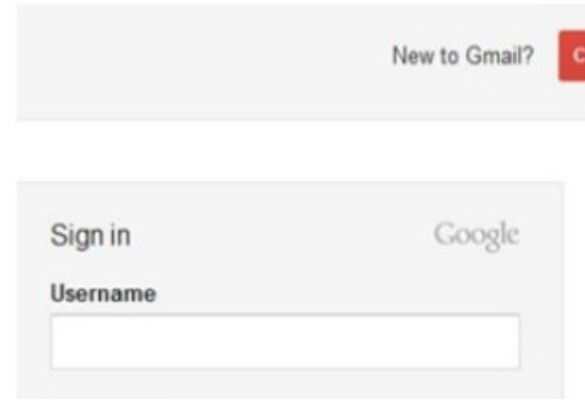

3. Lalu masukan identitas kamu pada formulir pendafta pengisian sangat mudah sekali, tidak jauh berbeda deng layanan email di Yahoo.com. Perhatikan contoh pengis
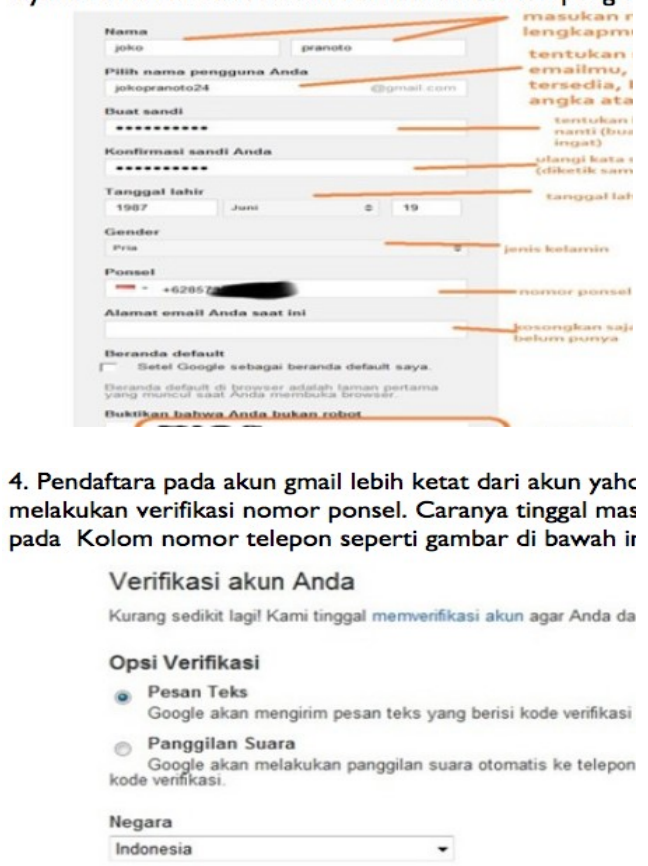
5. Setelah masukkan nomor ponsel, silahkan cek kota kamu. kamu akan mendapatkan sms kode verifikasi da bawah ini.

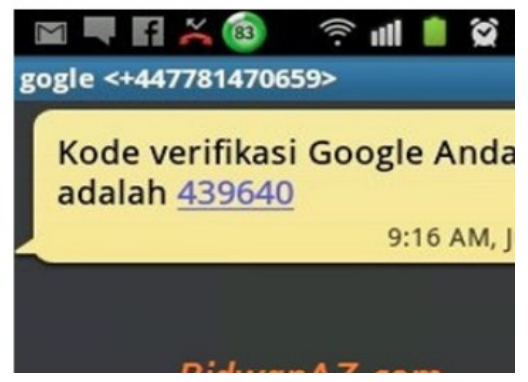

9. Nah, seperti inilah tampilan antar muka Dashboard kamu bisa menulis email, mengirim email, menerima er email. Selain itu kamu juga bisa chating langsung denga pengguna gmail.

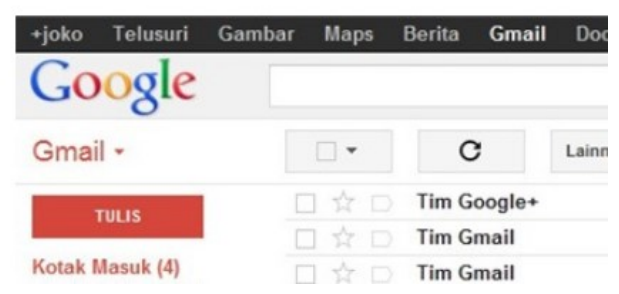

Gambar 7. Pembuatan Akun Gmail

b. Pembuatan akun facebook

Langkah-langkah pembuatan akun facebook (Kumiali, Sartika. 2009) telah dijelaskan pada saat pelatihan. Mitra membuat akun dengan bantuan tutorial dan melakukan capture hasil gambarnya dan dikirimkan kembali kepada tim pengabdian. Berikut gambar rangakaian proses pembuatan akun Facebook.

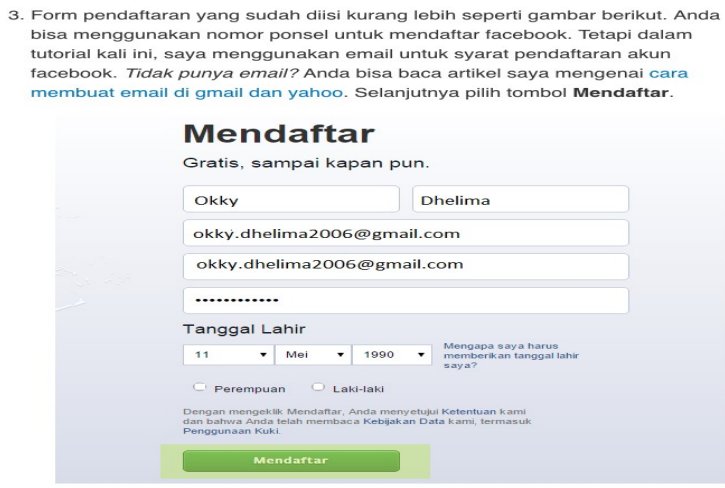

4. Akan muncul tiga langkah mudah untuk memulai face yaitu menambahkan orang yang mungkin anda kenal mencari teman nanti, jadi pilih Selanjutnya.

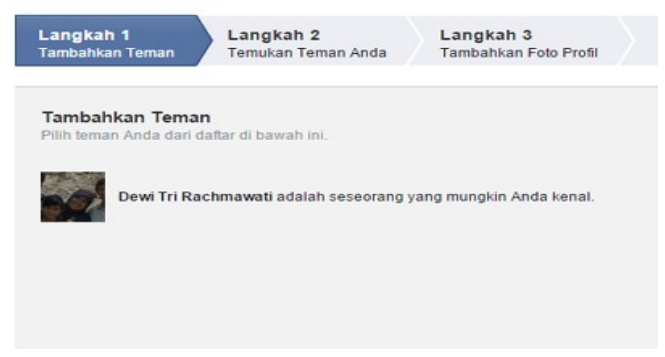

5. Untuk langkah yang kedua hampir sama dengan lar menambahkan teman. Bedanya, pada langkah ini ki melalui daftar email kita. Silakan pilih Selanjutnya, । langkah.

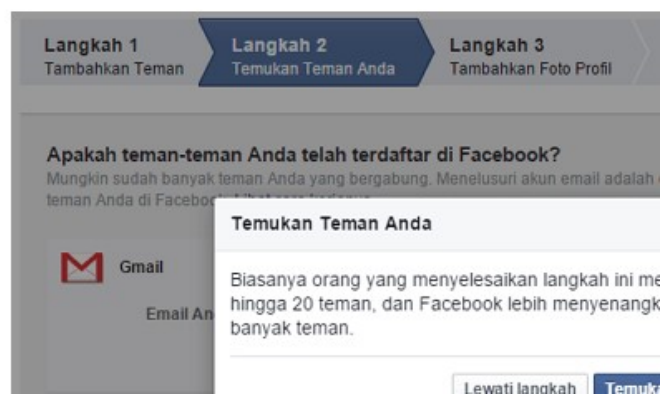

6. Anda bisa mengganti foto profil anda pada langkah ketiga ini. Pilih Selanjutnya saja, nanti saya akan jelaskan juga cara mengganti foto profil sekaligus foto sampulnya.

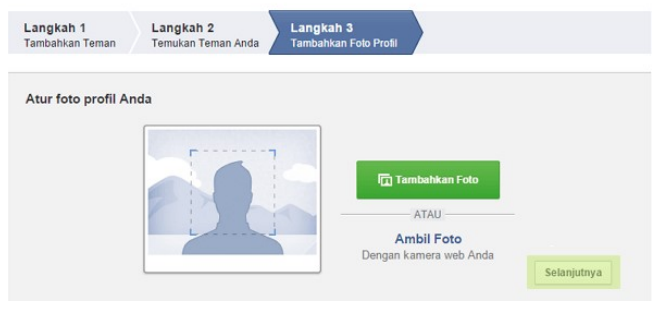

7. Untuk tahap terakhir pembuatan akun facebook, and anda. Silakan buka email dari facebook, kemudian kl Anda".

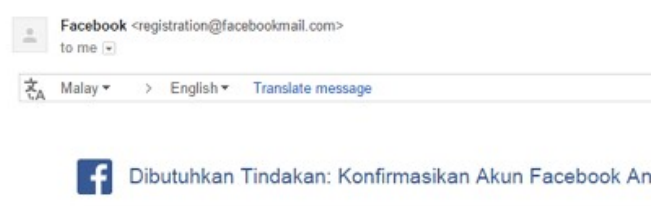

Gambar 8. Pembuatan Akun Facebook 
c. Mendaftar di marketplace

Berikut adalah langkah-langkah pembuatan akun pada marketplace Wiradarma IGN, Sukarsa I Made, Sutramiani Ni Putu. 2019). Untuk contoh marketplace yang digunakan pada saat pelatihan adalah shopee. Tampilan untuk mendaftar pada marketplace shopee dapat dilhat pada Gambar 9.

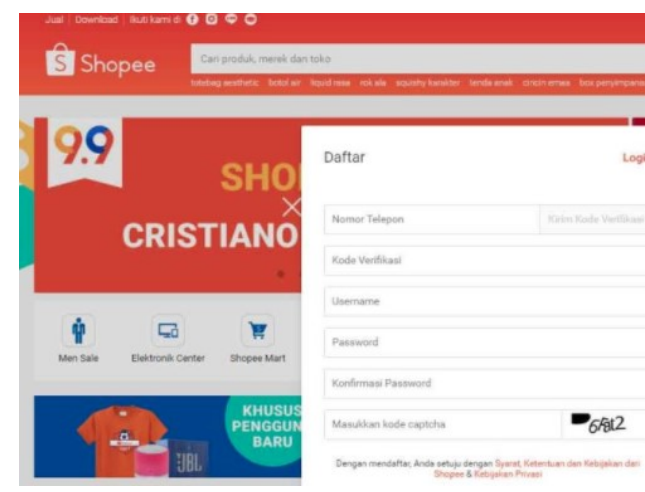

Gambar 9. Pendaftaran di Marketplace Shopee

\section{Diskusi dan Evaluasi}

Pada tahap akhir kegiatan pengabdian masyarakat ini dilakukan proses diskusi dan evaluasi antara tim pengabdian dengan mitra. Dikusi yang dilakukan terkait bagaimana melakukan digital marketing atau pemasaran dengan menggunakan teknologi informasi dan komunikasi agar usagha dari UKM Okky Dhelima Decoration ini dapat diterima dan menguasai pasar khususnya di kabupaten Karangasem. Pada saat evaluasi, tim mencoba kepada mitra untuk mlakukan sebuah pemasaran melalui akun facebook ataupun marketplace, untuk memastikan bahwa kegiatan ini bisa diterima oleh mitra.

Ada beberapa hal yang dapat diukur terkait dengan luaran kegiatan pelaksanaan
Pengabdian Masyarakat yang dilakukan kepada UKM Okky Dhelima Decoration, di antaranya adalah:

1. Memahami tentang digital marketing.

2. Menyadari pentingnya pemasaran dengan menggunakan teknologi informasi dan komunikasi.

3. Penetrasi pasar yang didapatkan ketika sudah menggunakan teknik pemasaran secara digital.

Sebelum adanya pelaksanaan kegiatan pengabdian masyarakat ini, UKM Okky Dhelima Decoration hanya mengenal pemasaran secara tradisional yaitu dengan memanfaatkan informasi yang diberikan secara mandiri atau mulut ke mulut oleh para pelanggan yang pernah menggunakan jasa dari UKM Okky Dhelima Decoration. Dari lima macam teknik pemasaran secara digital yang diinisiasi yaitu pemasaran meggunakan Whatssapp, pemasaran menggunakan media sosial facebook, pemasaran menggunakan media sosial instagram, pemasaran dengan menggunakan web, dan pemasaran menggunakan marketplace, UKM Okky Dhellima Decoration baru mengetahui jenis pemasaran menggunakan whatsapp atau 1 dari 5 teknik yang diinisiasi. Jika diprosentasi maka prosentasenya sebesar $1 / 5 \times 100 \%=20 \%$ saja. Setelah dilakukan kegiatan pengabdian masyarakat, UKM Okky Dhelima Decoration memahami seluruh teknik pemasaran yang telah diinisiasi atau $5 / 5 \times 100 \%=100 \%$.

Untuk penggunaan teknologi informasi dan komunikasi sebelum tim melakukan kegiatan pengabdian masyarakat ini dari 5 macam teknologi pemasaran yang disebutkan pada paragraf di atas, UKM Okky Dhellima Decoration juga hanya 
baru memanfaatkan 1 dari 5 teknologi pemasaran secara digital yang disebutkan, atau jika diprosentasi sebesar $1 / 5 \times 100 \%$ $=20 \%$. Setelah dilakukan kegiatan dan pelatihan, mitra melakukan pemasaran dengan menggunakan 5 macam teknologi informasi yang disebutkan di atas. UKM Okky Dhelima Decoration dapat menguasai, sehingga jika diprosentasekan sebesar $5 / 5 \times 100 \%=100 \%$.

Dari 8 kecamatan dan 75 desa yang terdapat di Kabupaten Karangasem, penetrasi pasar atau luasnya jangakauan pemasaran usaha UKM Okky Dhellima Decoration sebelum adanya kegiatan ini hanya berkisar pada kecamatan Karangasem, Kubu, dan Manggis saja dari 8 kecamatan yaitu Abang, Bebandem, Karangasem, Kubu, Manggis, Rendang, Selat, dan Sidemen. Jika diprosentase maka hanya berkisar $3 / 8 \times 100 \%=37,5 \%$. Setelah dilakukan pelatihan pemasaran secara digital, penetrasi pemasaran untuk di kabupaten Karangasem dapat mencapai seluruh kecamatan aitu $8 / 8 \times 100 \%=$ $100 \%$.

Tabel 4.1 Luaran Kegiatan Pengabdian

\begin{tabular}{|l|c|c|}
\hline Parameter & $\begin{array}{c}\text { Sebelum } \\
\text { Pengabdian }\end{array}$ & $\begin{array}{c}\text { Setelah } \\
\text { Pengabdian }\end{array}$ \\
\hline $\begin{array}{l}\text { Digital } \\
\text { Marketing }\end{array}$ & $20 \%$ & $100 \%$ \\
\hline $\begin{array}{l}\text { Penguasaan } \\
\text { Teknologi }\end{array}$ & $20 \%$ & $100 \%$ \\
\hline $\begin{array}{l}\text { Penetrasi } \\
\text { Pasar }\end{array}$ & $37,5 \%$ & $100 \%$ \\
\hline
\end{tabular}

Pada evaluasi kegiatan ini dilakukan proses penggalian informasi terkait dengan kegiatan pengabdian yang telah dilakukan.
Instrumen yang digunakan pada saat evaluasi ini adalah kuesioner dengan cara daring menggunakan google form. Gambar 10 adalah kuesioner evaluasi menggunakan google form.

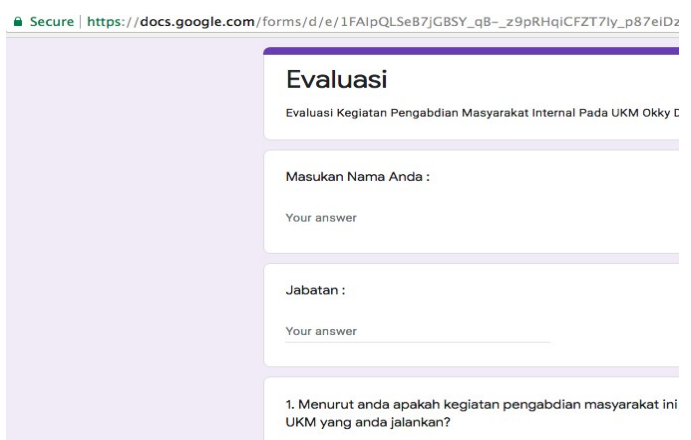

Gambar 10. Kuesioner Kegiatan

Adapun hasil kuesioner dari evaluasi yang dilakukan menggunakan google form dengan instrumen kuesioner adalah terlihat pada Gambar 11.

- Secure | https://docs.google.com/forms/d/1cyg_XBAPMLOJwwKZnrwmZN107yJDDsY, led form $\square$ All changes saved in orive

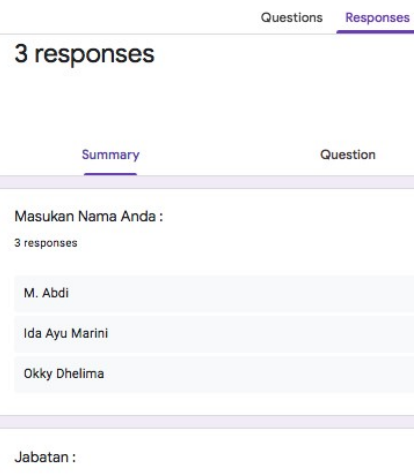




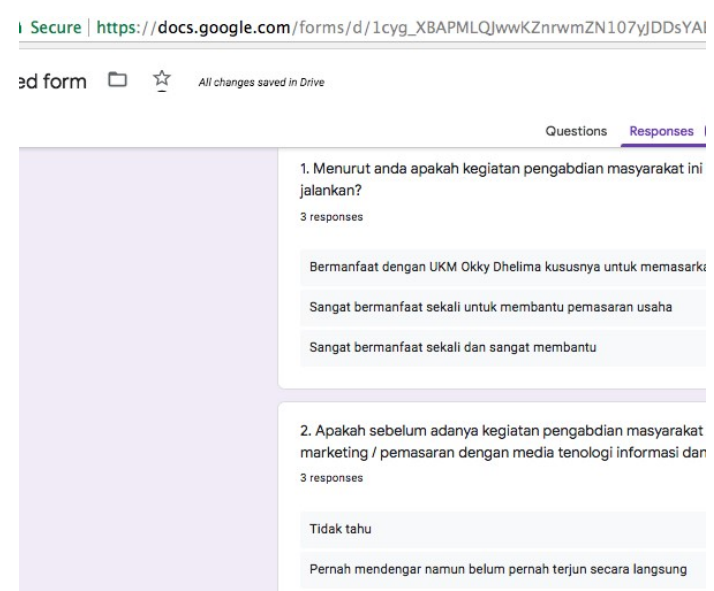

Gambar 11. Hasil Kuesioner Kegiatan

\section{Penutupan}

Sesi terakhir dari kegiatan ini adalah penutupan, dikarenakan kegiatan ini dilakukan secara daring maka penutupan dilakukan secara singkat.

\section{SIMPULAN}

Beberapa kesimpulan yang didapatkan dari hasil pengabdian ini di antaranya adalah sebagai berikut.

1. Kegiatan Pengabdian Kepada Masyarakat ini telah memberikan manfaat berupa adanya media pemasaran yang sebelumnya tidak dimiliki oleh Mitra yakni berupa media sosial facebook dan marketplace shopee, di mana media ini secara efektif dapat memperkenalkan usaha UKM Okky Dhelima Decoration.

2. UKM Okky Dhelima Decoration telah menyadari bahwa teknologi informasi dan komunikasi, media sosial, dan marketplace sangat berguna dalam pemasaran usaha yang mereka jalankan saat ini.

Berdasarkan pelaksanan pengabdian masyarakat, maka saran yang dapat disampaikan untuk kegiatan pengabdian yang telah dilakukan adalah :

1. UKM Okky Dhelima Decoration sebaiknya membangun sebuah company profile dan dapat dipublish melalui internet.

2. UKM Okky Dhelima Decoration kedepannya mempunyai sistem berbasis web yang dapat digunakan untuk trasnsaksi, pemasaran, dan membarikan infomasi yang terkait dengan usaha yang dijalankan.

\section{UCAPAN TERIMA KASIH}

Terima kasih disampaikan kepada ITB STIKOM Bali atas dukungan dana yang diberikan untuk melaksanakan kegiatan ini melalui program Pengabdian Masyarakat Internal Semester Genap 2019/2020 ITB STIKOM Bali.

\section{DAFTAR PUSTAKA}

http://v2.karangasemkab.go.id/index.php/p rofil, Profil Kabupaten Karangasem, Diakses tanggal 8 Juni 2020

https://metrobali.com/tinggi-penggunainternet-di-bali, Pengguna Internet di Bali, Diakses pada tanggal 8 Juni 2020

Helianthusonfri, Jefferly. 2017. "Facebook Marketing", Jalarta : PT. Gramedia Pustaka Utama

Kumiali, Sartika. 2009. “ Step by step Facebook". Jakarta : Elek Media Komputindo.

Marahimin, Hiang. 2008. "Masakan Selera Indonesia", Jakarta : PT. Gramedia Pustaka Utama.

Wiradarma IGN, Sukarsa I Made, Sutramiani Ni Putu. 2019. Rancang bangun Sistem E-Commerce Marketplace Gypsum Berbasis Cloud 
WIDYABHAKTI

JURNAL ILMIAH POPULER 2(3): 146-156

Computing". Jurnal Merpati Vol .7 No.1, ISSN:2252-3006.

Yuswohady, F.Fatahillah, B.Tryaditia,
A.Rachmaniar. 2019. "Millenials Kills Everything”. Jakarta : Gramedia Pustaka Utama. 